\title{
Transvenous Obliteration Procedure in the Management of Parastomal Variceal Bleeding: A Case Report
}

\author{
João Estorninho ${ }^{a}$ Pedro Patrão $^{b}$ Maria José Temido ${ }^{a}$ David Perdigoto ${ }^{a, c}$ \\ Pedro Figueiredo $^{a, c}$ Paulo Donato ${ }^{b, c}$ \\ aGastroenterology Department, Centro Hospitalar e Universitário de Coimbra, Coimbra, Portugal; ${ }^{\text {RRadiology }}$ \\ Department, Centro Hospitalar e Universitário de Coimbra, Coimbra, Portugal; 'FFaculty of Medicine, University of \\ Coimbra, Coimbra, Portugal
}

\section{Keywords}

Parastomal varices - Balloon-occluded retrograde transvenous obliteration - Transjugular intrahepatic portosystemic shunt

\begin{abstract}
Introduction: Parastomal variceal bleeding (PVB) is a recognized complication of ostomized patients in the presence of portal hypertension. However, since there are few reported cases, a therapeutic algorithm has not yet been established. Case Presentation: A 63-year-old man, who had undergone a definitive colostomy, recurrently presented to the emergency department hemorrhage of bright red blood from his colostomy bag, initially assumed to be caused by stoma trauma. Accordingly, temporary success on local approaches such as direct compression, silver nitrate application and suture ligation was achieved. However, bleeding recurred, requiring transfusion of red blood cell concentrate and hospitalization. The patient's evaluation showed chronic liver disease with massive collateral circulation, particularly at the colostomy site. After a PVB with associated hypovolemic shock, the patient was submitted to a balloon-occluded retrograde transvenous obliteration (BRTO) procedure which stopped the bleeding successfully. The patient was subsequently proposed for a transjugular intrahepatic portosystemic shunt (TIPS) conjugated with per-
\end{abstract}

cutaneous transhepatic obliteration (PTO). After an initial refusal by the patient, a new episode of self-limited PVB resulted in execution of the procedure. Four months later, in a routine consultation, the patient presented with grade II hepatic encephalopathy, successfully treated with medical therapy. After a 9-month follow-up, he remained clinically well and without further episodes of PVB or other adverse effects. Discussion: This report highlights the importance of a high index of suspicion when dealing with significant stomal hemorrhage. Portal hypertension as an etiology of this entity may compel to a specific approach to prevent recurrence of bleeding, including conjugation of endovascular procedures. The authors present a case of PVB, initially submitted to a variety of treatment options including BRTO, which was successfully addressed with conjugated treatment of TIPS and PTO.

\section{(C) 2022 Sociedade Portuguesa de Gastrenterologia Published by S. Karger AG, Basel}

\section{Obliteração transvenosa na abordagem da hemorragia de varizes periestoma: relato de caso \\ Palavras chave \\ Varizes peristomais · Obliteração transvenosa retrógrada ocluída por balão - Shunt portossistémico transjugular intra-hepático}

Karger@karger.com www.karger.com/pjg

Karger $\stackrel{\text { ' }}{5}$

BOPEN ACCESS (c) 2022 Sociedade Portuguesa de Gastrenterologia. Published by S. Karger AG, Basel

This is an Open Access article licensed under the Creative Commons Attribution-NonCommercial-4.0 International License (CC BY-NC) (http://www.karger.com/Services/OpenAccessLicense), applicable to the online version of the article only. Usage and distribution for commercial purposes requires written permission.
Correspondence to:

João Estorninho, estorninhoalves@gmail.com 


\section{Resumo}

Introdução: A hemorragia de varizes periestomais é uma complicação conhecida de doentes ostomizados com hipertensão portal. Contudo, devido ao pequeno número de casos descritos, ainda não foi estabelecido um algoritmo terapêutico. Apresentação do caso: Homem, 63 anos, com antecedentes de colostomia definitiva, recorre ao Serviço de Urgência recorrentemente por sangue vivo no saco de colostomia. Inicialmente, presumindo-se trauma do estoma, foi submetido a tratamentos locais, como compressão, aplicação de nitrato de prata e sutura, com sucesso temporário. Contudo, houve recorrência da hemorragia, com necessidade de suporte transfusional e hospitalização. A avaliação do doente evidenciou doença hepática crónica com circulação colateral exuberante, predominantemente junto da colostomia. Devido a hemorragia com choque hipovolémico, foi submetido a obliteração transvenosa retrógrada ocluída por balão (BRTO). Posteriormente, foi proposto para shunt portossistémico transjugular intra-hepático (TIPS) conjugado com obliteração transhepática percutânea (PTO). Após recusa inicial do doente, ocorreu novo episódio de hemorragia autolimitado, tendo o doente concordado em realizar o procedimento. Quatro meses depois, em consulta, apresentava sinais de encefalopatia hepática grau II, tendo sido controlada eficazmente com tratamento médico. Após nove meses de seguimento, mantém-se sem novos episódios de hemorragia ou efeitos adversos dos procedimentos. Discussão: É necessário um alto índice de suspeição clínica ao abordar a hemorragia significativa do estoma. A hipertensão portal como etiologia exige uma abordagem específica para prevenir a recorrência da hemorragia, incluindo a conjugação de procedimentos endovasculares. Os autores apresentam o caso de um doente com hemorragia de varizes periestomais submetido inicialmente a vários tratamentos, incluindo BRTO e que foi tratado com sucesso com TIPS e PTO.

(c) 2022 Sociedade Portuguesa de Gastrenterologia. Publicado por S. Karger AG, Basel

\section{Introduction}

Varices are abnormally large portosystemic venous collaterals most commonly recognized near the gastroesophageal junction. Varices that appear in other gastrointestinal locations are called ectopic. Although unusual, they can account for up to $5 \%$ of all variceal hemorrhages [1].

Parastomal varices (PV) usually occur in ostomized patients with chronic liver disease (CLD) and emerge at

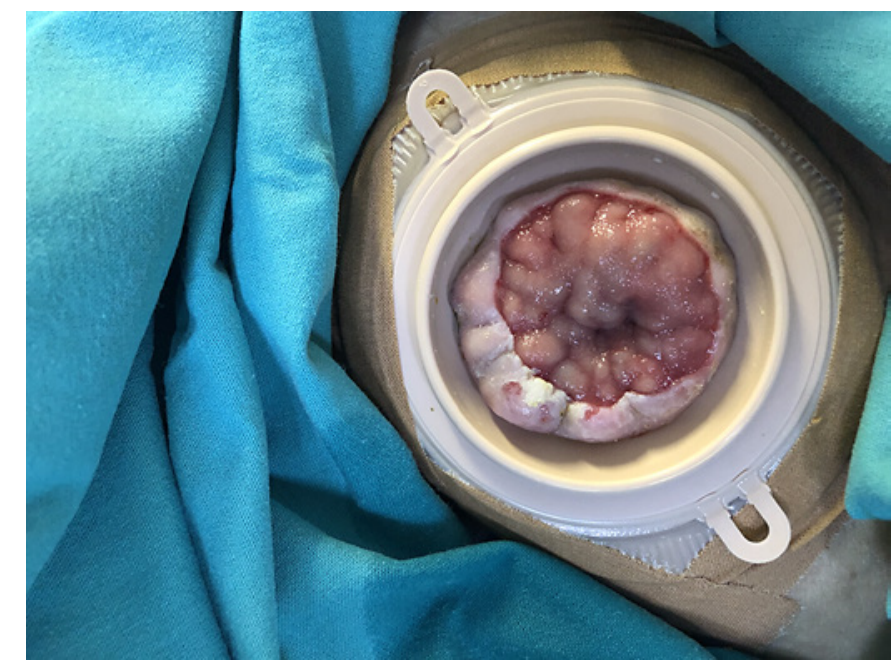

Fig. 1. Colostomy stoma, with visibly dilated submucosal veins and keratosis of the colon mucosa around it.

the mucocutaneous junction of the stoma. PV develop due to a portosystemic shunt between the portal circulation of the bowel and systemic circulation of the abdominal wall. There are no pathognomonic physical symptoms or signs of PV. A raspberry appearance of the stoma with visibly dilated submucosal veins and bluish discoloration and hyperkeratosis of the surrounding skin have been used to describe PV [2].

Doppler ultrasound, computed tomography (CT) and magnetic resonance angiography may identify varices in the region of the stoma and facilitate the diagnosis of CLD, portal hypertension and the assessment of portal patency [3].

Parastomal variceal bleeding (PVB) tends to present as chronic and recurrent rather than massive bleeding, although the need for a blood transfusion is expected in $42.9 \%$ [4]. The mortality rate of PVB is estimated at around $3-4 \%[2,3]$. Despite the low mortality rate, given its insidious but recurring nature, greater awareness and an established therapeutic strategy will certainly be useful.

\section{Case Presentation}

A 63-year-old man presented to the emergency department several times throughout 1 year with self-limited bright red blood in his colostomy bag. The patient had undergone abdominoperineal resection (with permanent colostomy) due to rectal carcinoma 4 years earlier. Initially, stoma bleeding due to local trauma was presumed. In the majority of those episodes, no bleeding source 
Fig. 2. Intravenous contrast-enhanced CT coronal (a) and sagittal (b) images of the abdomen with multiple varices (arrows) within the left lower quadrant stoma.
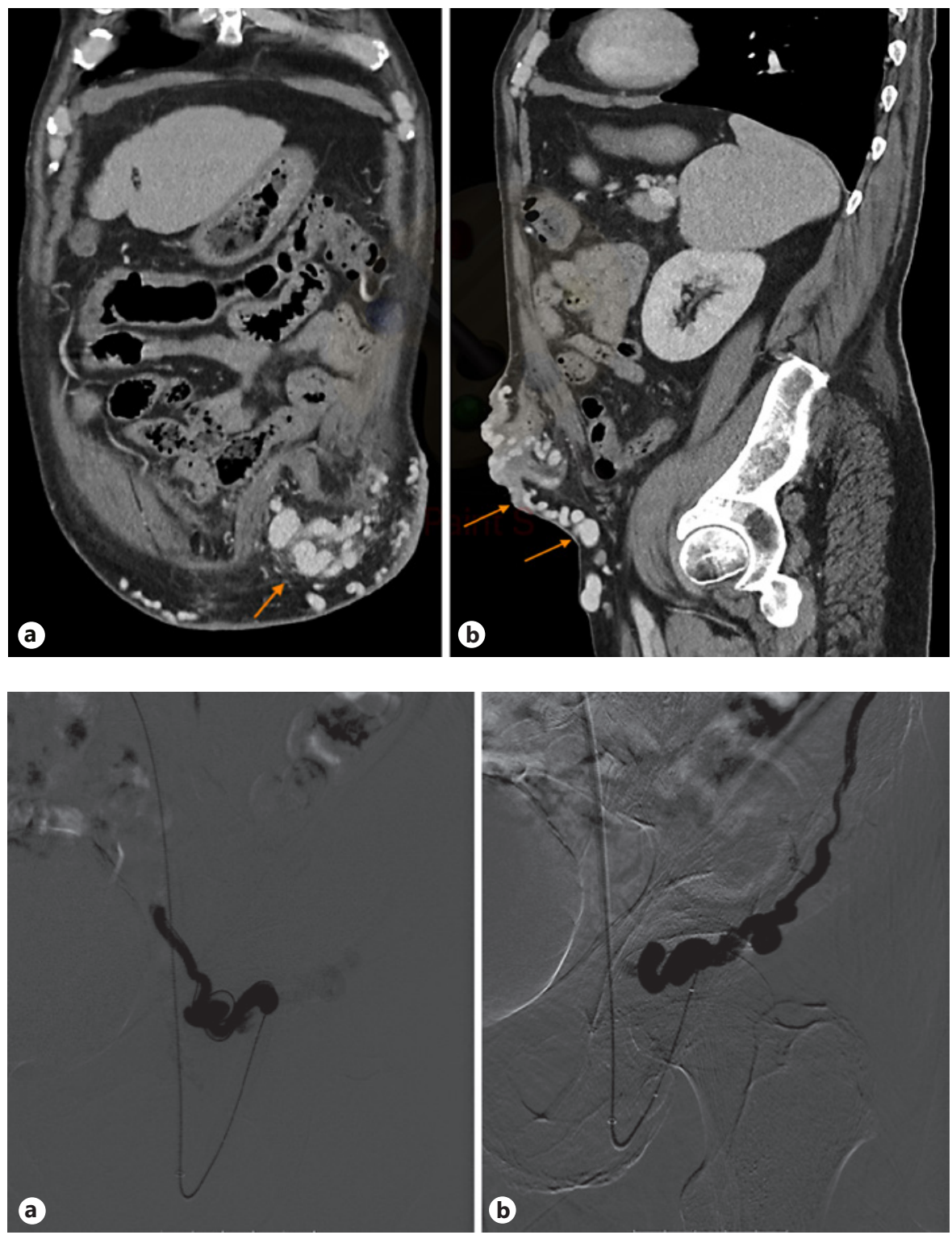

Fig. 3. Retrograde transvenous venogram from the systemic venous side of the system showing multiple parastomal systemic draining veins coursing along the medial (a) and lateral (b) aspect of the stoma. dominal wall, giving rise to multiple varicose veins. Many of the varices were converging in the stoma, and others were running through the thickness of the lower abdominal wall, draining distally into the left common femoral vein (LCFV) (Fig. 2). The portal vein was patent.

Due to an episode of acute spurting bleeding with hypovolemic shock during hospital admission, the patient was initiated on terlipressin and agreed to be submitted to a balloon-occluded retrograde transvenous obliteration (BRTO) procedure. Through the right femoral approach, a balloon catheter was placed at the portosystemic shunt drainage site in the LCFV. A 6-F guiding sheath at the left external iliac vein was used for extra catheter support. After balloon inflation, a retrograde transvenous venogram from the systemic venous side of the system was performed, demonstrating multiple parastomal systemic draining veins (Fig. 3). A 2.7 $\mathrm{F} \times 130 \mathrm{~cm}$ Progreat microcatheter (Terumo, Tokyo, Japan) was 


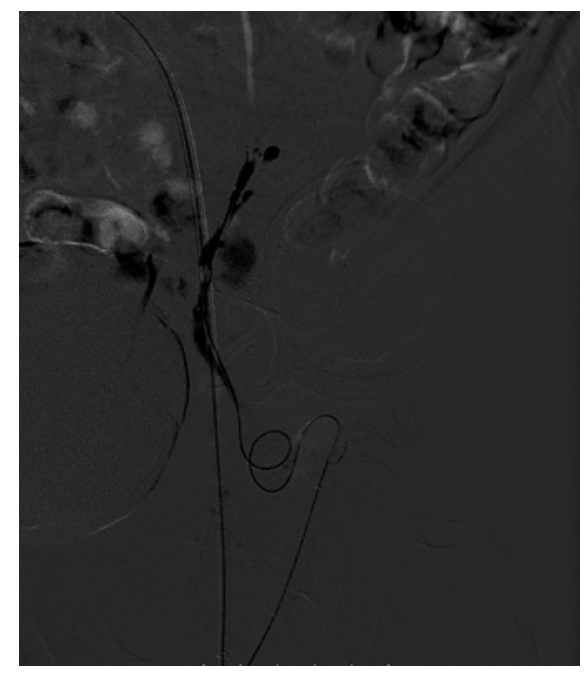

Fig. 4. Phlebography after distal catheterization of the varicose plexus using a microcatheter.

Fig. 5. a Venogram taken near the end of the "BRTO approach", after glue embolization. b Final venogram showing exclusion of varicose drainage into the left femoral vein. used for distal (rather proximal from a blood flow standpoint) selective catheterization of these efferent systemic draining veins (Fig. 4). N-butyl-2-cyanoacrylate embolization of PV was performed (Fig. 5). Postembolization control evaluation revealed exclusion of varicose drainage in the LCFV. The procedure proceeded uneventfully, with bleeding resolution.

The case was subsequently discussed in a multidisciplinary team meeting. Considering the preeminence of PV, with multiple portosystemic shunts, it was concluded that local obliteration of the remaining collaterals assisted by endoscopic ultrasound alone was not feasible. The patient was then proposed for a transjugular intrahepatic portosystemic shunt (TIPS) conjugated with percutaneous transhepatic obliteration (PTO).

Fearing possible complications, such as the development of hepatic encephalopathy (HE), the patient refused the procedure at first. Nevertheless, 7 days after BRTO, following terlipressin suspension and initiation of propranolol, the patient experienced a new episode of self-limited PVB and agreed to undergo the proposed treatment. Through the right internal jugular vein access, the right suprahepatic vein was selected and shunted with the right
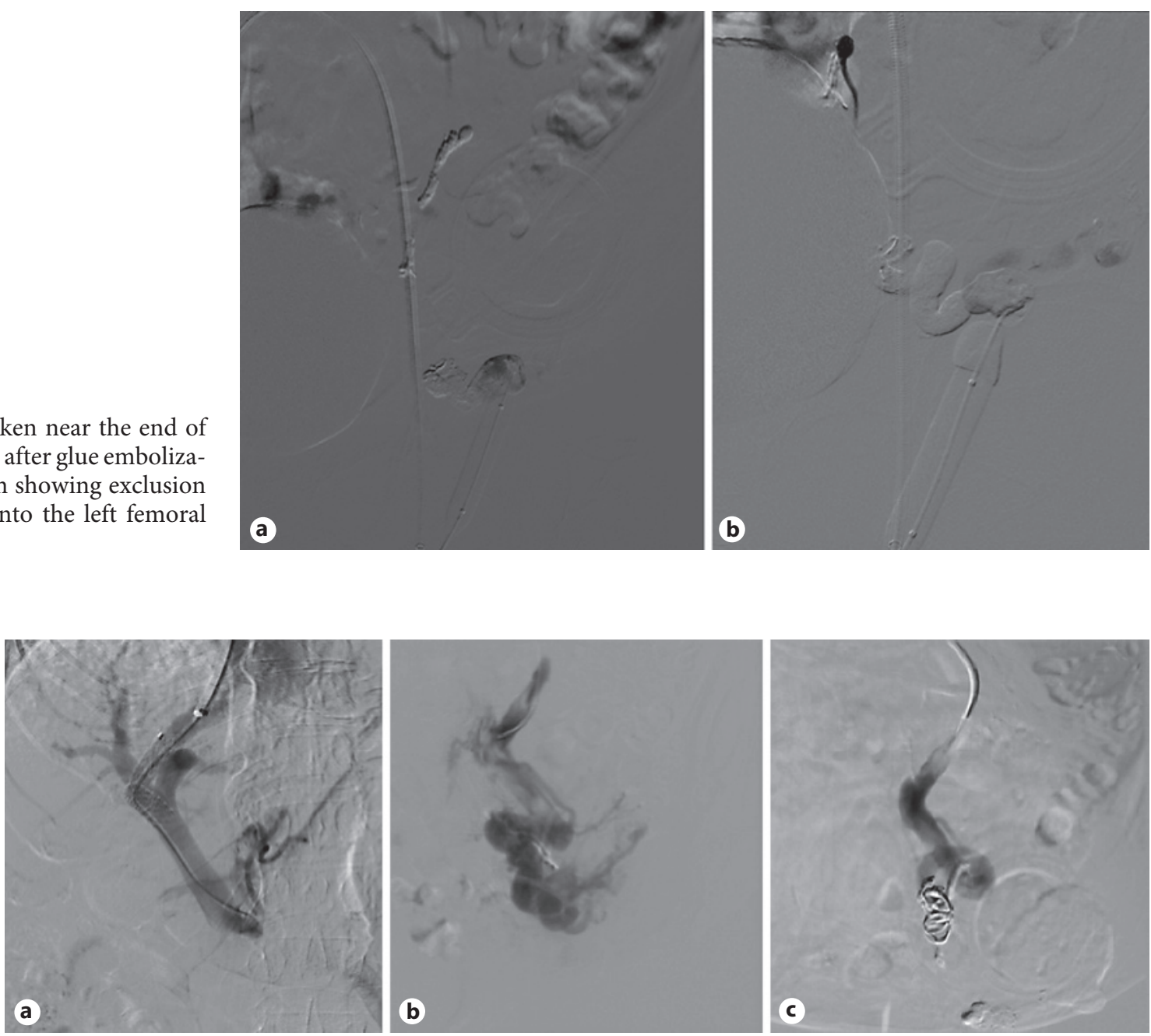

Fig. 6. a Transhepatic approach after TIPS prosthesis has been placed. b Stoma varicose plexus being selected. c Embolization of the main varix with coils. 
branch of the portal vein. Upon tract balloon dilation, an 8-10 mm $\times 5 \mathrm{~cm}$ Viatorr TIPS prosthesis (W.L. Gore, Flagstaff, AZ, USA) was placed, resulting in a hepatic-venous pressure gradient (HVPG) reduction from 20 to $14 \mathrm{~mm} \mathrm{Hg}$. After selective catheterization of the inferior mesenteric vein, an anterograde transvenous venogram was performed, demonstrating multiple pericolostomy varicose veins. In phlebographic control, the pericolostomy varicose plexus was selected, with embolization of the main varix with coils (Fig. 6). The procedure proceeded uneventfully.

Four months after the procedure, the patient presented with grade II HE in a routine hepatology consultation. Nevertheless, it was successfully managed with medical therapy (lactulose and rifaximin).

After a 9-month follow-up, the patient has remained well without further episodes of PVB or other adverse effects.

\section{Discussion}

Significant parastomal bleeding must raise suspicion of portal hypertension and underlying CLD, which have to be actively excluded. The management of PVB should involve a multidisciplinary approach (with hepatologists, interventional radiologists and surgeons), with a progressive escalade in more invasive methods when local procedures are not effective. Concomitant treatment of CLD should be carried out, particularly removing the etiological factor(s) causing liver injury whenever possible $[3,4]$.

Simple local procedures, such as pressure dressings, epinephrine-soaked gauze, gel foam, and suture ligation have been used with success on the initial bleeding episode. However, bleeding recurrence is the rule [2-4].

Some treatments have shown considerable morbidity and/or recurrence, not being valuable options in the management of this pathology. These include sclerotherapy, which resulted in stomal damage and/or recurrent bleeding in nearly all patients [5]. Mucocutaneous disconnection and surgical relocation of the stoma were also associated with recurrent bleeding and significant perioperative surgical risk [6].

From a pathophysiological point of view, pharmacotherapy used in gastroesophageal varices management may be applied in patients with PVB by reducing HVPG [7]. However, data on the role of medical therapy in PVB is scarce. $\beta$-Blockers have presented conflicting results: older studies showed that they are not effective in PVB [4], while a few recent clinical reports showed they may delay their recurrence [8]. In 2 patients with contraindications for intravascular procedures, octreotide showed to be effective as a palliative care option, without significant side effects, suggesting it can be consid- ered for patients for whom noninterventional care is indicated [9].

Minimally invasive endovascular techniques guided by ultrasound or CT have been safely used in the management of PVB. The simplest and least invasive procedure is direct ultrasound-guided percutaneous embolization with cyanoacrylate or coils. Nevertheless, this technique showed better results when a single dominant varix is identified and has an increased risk of embolization glue migration and mucosal damage at the stomal site. A proposed way to minimize glue migration is to combine this modality with ultrasound-guided systemic venous compression $[10,11]$.

The BRTO approach from the systemic venous side and PTO approach from the portal venous side are other endovascular techniques angiography-guided, which have been proving to be effective and safe. The main limitation to these procedures is long-term recurrence due to failure to embolize all feeding vessels, or due to the rapid development of new vessels [11-14].

Although embolization guided by endoscopic ultrasound has been tested successfully in PVB [15], minimal length necessity of intubation (which would make maintaining the endoscope position difficult) and the easier percutaneous approach make this modality unattractive [16].

Hypothetically, surgical portosystemic shunt can be considered as a decompressive measure [4]. However, given the increased morbidity, lower efficacy and inadequacy in transplant candidates, TIPS is clearly a preferred option. TIPS is by far the best-studied modality for managing PVB, as it ultimately reduces HVPG. Some limitations of TIPS are its contraindication in liver neoplasia and the risk of developing HE in advanced CLD (although it can usually be managed with medical treatment, as occurred in our patient). Moreover, even though it appears to be the most effective treatment modality, up to $25 \%$ of patients develop rebleeding. Although the common understanding has been that varices rarely bleed at HVPG less than $12 \mathrm{~mm} \mathrm{Hg}$, there were several cases of rebleeding by PV after TIPS despite lower HVPG $[17,18]$. This statement highlights the importance of other coadjuvant treatments such as BRTO or PTO, particularly in cases with higher HVPG, as was the case in our patient. These two modalities can be performed following bleeding recurrence after TIPS, when TIPS is contraindicated or, as in this case, to complement TIPS before and during this procedure. 


\section{Statement of Ethics}

The project was subjected to the standards of good clinical practice and always complied with the ethical precepts of the Helsinki Declaration. Written informed consent was obtained from the patient for publication of this case report and any accompanying images.

\section{Conflict of Interest Statement}

The authors have no conflicts of interest to declare.

\section{Funding Sources}

No funding was received.

\section{Author Contributions}

J. Estorninho: literature research, manuscript preparation and drafting; P. Patrão: manuscript preparation and drafting; M.J. Temido: manuscript preparation; D. Perdigoto: critical revision; P. Figueiredo and P. Donato: manuscript final approval.

\section{References}

1 Boregowda U, Umapathy C, Halim N, Desai M, Nanjappa A, Arekapudi S, et al. Update on the management of gastrointestinal varices. World J Gastrointest Pharmacol Ther. 2019; 10(1):1-21.

2 Norton ID, Andrews JC, Kamath PS. Management of ectopic varices. Hepatology. 1998; 28(4):1154-8.

3 Spier BJ, Fayyad AA, Lucey MR, Johnson EA, Wojtowycz M, Rikkers L, et al. Bleeding stomal varices: case series and systematic review of the literature. Clin Gastroenterol Hepatol. 2008;6(3):346-52.

4 Pennick MO, Artioukh DY. Management of parastomal varices: who re-bleeds and who does not? A systematic review of the literature. Tech Coloproctol. 2013;17(2):163-70.

5 Hesterberg R, Stahlknecht CD, Röher HD. Sclerotherapy for massive enterostomy bleeding resulting from portal hypertension. Dis Colon Rectum. 1986;29(4):275-7.

6 Beck DE, Fazio VW, Grundfest-Broniatowski S. Surgical management of bleeding stomal varices. Dis Colon Rectum. 1988;31(5):343-6.

7 Baiges A, Hernández-Gea V, Bosch J. Pharmacologic prevention of variceal bleeding and rebleeding. Hepatol Int. 2018;12(Suppl 1):68-80.
$8 \mathrm{Mu}$ X, Winsor W, Trahey J. Use of non-selective beta-blocker for refractory stomal variceal hemorrhage. Case Rep Gastroenterol. 2021 Jan-Apr;15(1):87-91.

9 Selby D, Jackson LD. Octreotide for control of bleeding peristomal varices in palliative care. J Pain Symptom Manage. 2015;49(3):e2-4.

10 Thouveny F, Aubé C, Konaté A, Lebigot J, Bouvier A, Oberti F. Direct percutaneous approach for endoluminal glue embolization of stomal varices. J Vasc Interv Radiol. 2008;19(5):774-7.

11 Saad WE, Saad NE, Koizumi J. Stomal varices: management with decompression tips and transvenous obliteration or sclerosis. Tech Vasc Interv Radiol. 2013;16(2):176-84.

12 Minami S, Okada K, Matsuo M, Kamohara Y, Sakamoto I, Kanematsu T. Treatment of bleeding stomal varices by balloon-occluded retrograde transvenous obliteration. J Gastroenterol. 2007;42(1):91-5.

13 Takano M, Imai Y, Nakazawa M, Chikayama T, Ando S, Sugawara K, et al. A case of liver cirrhosis with bleeding from stomal varices successfully treated using balloon-occluded retrograde transvenous obliteration. Clin J Gastroenterol. 2016;9(3):145-9.
14 Maciel MJ, Pereira OI, Motta Leal Filho JM, Ziemiecki E Jr, Cosme SL, Souza MA, et al. Peristomal variceal bleeding treated by coil embolization using a percutaneous transhepatic approach. World J Clin Cases. 2016; 4(1):25-9.

15 Tsynman DN, DeCross AJ, Maliakkal B, Ciufo N, Ullah A, Kaul V. Novel use of EUS to successfully treat bleeding parastomal varices with N-butyl-2-cyanoacrylate. Gastrointest Endosc. 2014;79(6):1007-8.

16 Chong VH. EUS and treatment of parastomal varices: is novelty important? Gastrointest Endosc. 2015;81(1):241.

17 Morris CS, Najarian KE. Transjugular intrahepatic portosystemic shunt for bleeding stomal varices associated with chronic portal vein occlusion: long-term angiographic, hemodynamic, and clinical follow-up. Am J Gastroenterol. 2000;95(10):2966-8.

18 Deipolyi AR, Kalva SP, Oklu R, Walker TG, Wicky S, Ganguli S. Reduction in portal venous pressure by transjugular intrahepatic portosystemic shunt for treatment of hemorrhagic stomal varices. AJR Am J Roentgenol. 2014;203(3):668-73. 